\title{
Hydrogen peroxide inhibits mTOR signaling by activation of AMPK $\alpha$ leading to apoptosis of neuronal cells
}

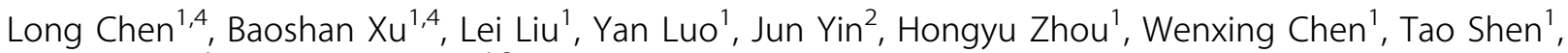 \\ Xiuzhen $\operatorname{Han}^{1}$ and Shile Huang ${ }^{1,3}$
}

Oxidative stress results in apoptosis of neuronal cells, leading to neurodegenerative disorders. However, the underlying molecular mechanism remains to be elucidated. Here, we show that hydrogen peroxide $\left(\mathrm{H}_{2} \mathrm{O}_{2}\right)$, a major oxidant generated when oxidative stress occurs, induced apoptosis of neuronal cells (PC12 cells and primary murine neurons), by inhibiting the mammalian target of rapamycin (mTOR)-mediated phosphorylation of ribosomal p70 S6 kinase (S6K1) and eukaryotic initiation factor 4E (elF4E)-binding protein 1 (4E-BP1). $N$-acetyl-L-cysteine (NAC), a scavenger of reactive oxygen species (ROS), blocked $\mathrm{H}_{2} \mathrm{O}_{2}$ inhibition of mTOR signaling. Ectopic expression of wild-type (wt) mTOR, constitutively active S6K1 or downregulation of $4 \mathrm{E}-\mathrm{BP} 1$ partially prevented $\mathrm{H}_{2} \mathrm{O}_{2}$ induction of apoptosis. Furthermore, we identified that $\mathrm{H}_{2} \mathrm{O}_{2}$ induction of ROS inhibited the upstream kinases, Akt and phosphoinositide-dependent kinase 1 (PDK1), but not the type I insulin-like growth factor receptor (IGFR), and activated the negative regulator, AMP-activated protein kinase $\alpha$ (AMPK $\alpha$ ), but not the phosphatase and tensin homolog (PTEN) in the cells. Expression of a dominant negative AMPK $\alpha$ or downregulation of AMPK $\alpha 1$ conferred partial resistance to $\mathrm{H}_{2} \mathrm{O}_{2}$ inhibition of phosphorylation of S6K1 and 4E-BP1, as well as cell viability, indicating that $\mathrm{H}_{2} \mathrm{O}_{2}$ inhibition of mTOR signaling is at least in part through activation of AMPK. Our findings suggest that AMPK inhibitors may be exploited for prevention of $\mathrm{H}_{2} \mathrm{O}_{2}$-induced neurodegenerative diseases.

Laboratory Investigation (2010) 90, 762-773; doi:10.1038/labinvest.2010.36; published online 8 February 2010

KEYWORDS: hydrogen peroxide; apoptosis; mammalian target of rapamycin; ribosomal p70 S6 kinase; eukaryotic initiation factor 4E-binding protein 1; AMP-activated kinase

Oxidative stress elicits elevated levels of reactive oxygen species (ROS), such as hydrogen peroxide $\left(\mathrm{H}_{2} \mathrm{O}_{2}\right)$, superoxide $\left(\mathrm{O}_{2}^{-}\right)$and hydroxyl radical $\left(\mathrm{HO}^{-}\right)$, which cause increased permeability of the blood-brain barrier, tubulin alterations, and perturbation in synaptic transmission, ${ }^{1}$ and are known to have an important function in neuronal cell death. $^{2}$ Therefore, ROS induction becomes a prominent feature of many neurodegenerative disorders, such as Alzheimer's disease, Parkinson's disease, and amyotrophic lateral sclerosis. Increasing evidence has further shown that under pathological conditions, excessive amounts of ROS can readily react with thiol groups of proteins, thereby disrupting the structure of cellular proteins and altering their functions, and also activate related signaling pathways, leading to neuronal apoptosis or neurodegeneration. ${ }^{3-9}$

The mammalian target of rapamycin (mTOR), a $289-\mathrm{kDa}$ serine/threonine (Ser/Thr) protein kinase, lies downstream of insulin-like growth factor 1 (IGF-1) receptor (IGFR). ${ }^{10}$ In response to ligand binding, IGFR, a transmembrane tyrosine kinase, is activated via auto-phosphorylation of multiple tyrosine residues. Activated IGFR phosphorylates the insulin receptor substrates, which in turn triggers activation of phosphatidylinositol $3^{\prime}$ kinase (PI3K). Activation of PI3K results in activation of PDK1, Akt, and mTOR, which is negatively regulated by phosphatase and tensin homolog (PTEN), a dual-specificity protein and lipid phosphatase.

\footnotetext{
${ }^{1}$ Department of Biochemistry and Molecular Biology, Louisiana State University Health Sciences Center, Shreveport, LA, USA; ${ }^{2}$ Department of Microbiology and Immunology, Louisiana State University Health Sciences Center, Shreveport, LA, USA and ${ }^{3}$ Feist-Weiller Cancer Center, Louisiana State University Health Sciences Center, Shreveport, LA, USA

Correspondence: Dr S Huang, PhD, Department of Biochemistry and Molecular Biology, Louisiana State University Health Sciences Center, 1501 Kings Highway, Shreveport, LA 71130-3932, USA.

E-mail: shuan1@|suhsc.edu
}

${ }^{4}$ These two authors contributed equally to this work.

Received 28 July 2009; revised 22 December 2009; accepted 4 January 2010 
Activated mTOR further phosphorylates ribosomal p70 S6 kinase (S6K1), eukaryotic initiation factor 4E (eIF4E)-binding protein 1 (4E-BP1), and Akt, controlling cell proliferation, growth, and survival. ${ }^{10,11}$ Activated PDK1 also positively regulates $\mathrm{S} 6 \mathrm{~K} 1 .^{10}$ Studies have placed tuberous sclerosis complex (TSC) $1 / 2$ as a modulator between PI3K/ Akt and mTOR. ${ }^{12-14}$ The TSC1/2 complex acts as a repressor of mTOR function. ${ }^{12-14}$ TSC2 has GTPase-activating protein (GAP) activity toward the Ras family small GTPase Rheb (Ras homolog enriched in brain), and TSC1/2 antagonizes the mTOR signaling pathway via stimulation of GTP hydrolysis of Rheb. ${ }^{15-20}$ Rheb activates mTOR by antagonizing its endogenous inhibitor, FKBP38, ${ }^{21}$ though this remains controversial. ${ }^{22}$ The TSC can also be activated by energy depletion through the activation of AMP-activated kinase (AMPK). ${ }^{23}$ AMPK responds both to changes in AMP concentration and to changes in the ratio of AMP to ATP. ${ }^{24} \mathrm{An}$ increased AMP to ATP ratio allows AMPK phosphorylation and activation. ${ }^{24}$ This, in turn, activates the TSC, which catalyzes the conversion of Rheb-GTP to Rheb-GDP and thus inhibits mTOR. ${ }^{23}$ AMPK can also be phosphorylated and activated by the calcium- and calmodulin-dependent protein kinase kinase- $\beta$ (CaMKK- $\beta$ ) in response to alterations in intracellular calcium homeostasis. ${ }^{25}$ In addition, AMPK may be activated by oxidative stress. ${ }^{25}$

Recently, we have shown that $\mathrm{H}_{2} \mathrm{O}_{2}$ induces neuronal apoptosis, which is associated with the inhibition of protein phosphatase $2 \mathrm{~A}$ and protein phosphatase 5 , leading to activation of MAPK pathway. ${ }^{9}$ Here, we further show that $\mathrm{H}_{2} \mathrm{O}_{2}$ induced ROS inhibited mTOR-mediated phosphorylation of S6K1 and 4E-BP1 in PC12 cells and primary murine neurons. Furthermore, we identified that $\mathrm{H}_{2} \mathrm{O}_{2}$ induction of ROS inhibited the upstream kinases, Akt and PDK1, but not IGFR, and activated the negative regulator, AMPK $\alpha$, but not PTEN in the cells. Expression of a dominant negative AMPK $\alpha$ or downregulation of AMPK $\alpha 1$ conferred partial resistance to $\mathrm{H}_{2} \mathrm{O}_{2}$ inhibition of phosphorylation of $\mathrm{S} 6 \mathrm{~K} 1$ and $4 \mathrm{E}-\mathrm{BP} 1$, as well as cell viability, indicating that $\mathrm{H}_{2} \mathrm{O}_{2}$ inhibition of mTOR signaling is at least in part through activation of AMPK.

\section{MATERIALS AND METHODS Materials}

Hydrogen peroxide (30\%) was purchased from Sigma (St Louis, MO, USA). Dulbecco's Modified Eagle Medium (DMEM) was provided by Mediatech (Herndon, VA, USA). Horse serum and fetal bovine serum (FBS) were from Hyclone (Logan, UT, USA), whereas $0.05 \%$ Trypsin-EDTA, NEUROBASAL Media, and B27 Supplement were from Invitrogen (Carlsbad, CA, USA). Enhanced chemiluminescence solution was from Pierce (Rockford, IL, USA). CellTiter 96 $\mathrm{AQ}_{\text {ueous }}$ One Solution Cell Proliferation Assay kit was from Promega (Madison, WI, USA). Caspase-3/7 Assay Kit (Cat.\# 71118) was purchased from AnaSpec, Inc. (Fremont, CA, USA). The following antibodies were used: phospho-AMPK $\alpha$ (Thr172), acetyl-CoA carboxylase (ACC), phospho-ACC
(Ser79), phospho-mTOR (Ser2448), mTOR, phospho-Akt (Ser473), S6 ribosomal protein, phospho-S6 ribosomal protein (Ser235/236) (all from Cell Signaling Technology, Beverly, MA, USA); hemagglutinin (HA), IGFR $\beta$ subunit (IGFR $\beta$ ), Akt, AMPK $\alpha$, phospho-S6K1 (Thr389), S6K1 (all from Santa Cruz Biotechnology, Santa Cruz, CA, USA); 4EBP1 (Zymed Laboratories, South San Francisco, CA, USA); Phosphotyrosine (BD Biosciences, San Jose, CA, USA); FLAG and $\beta$-tubulin (Sigma); goat anti-rabbit IgG-horseradish peroxidase (HRP), goat anti-mouse IgG-HRP, and rabbit anti-goat IgG-HRP (Pierce). N-acetyl-L-cysteine (NAC), Poly-D-lysine (PDL), papain, DNasel and all the other chemicals were purchased from Sigma.

\section{Cell Culture}

Rat pheochromocytoma (PC12) and SH-SY5Y cell lines were purchased from American Type Culture Collection (ATCC) (Manassas, VA, USA). PC12 cells were used for no more than 10 passages, and were in antibiotic-free DMEM supplemented with $10 \%$ horse serum and 5\% FBS, whereas SH-SY5Y cells were grown in antibiotic-free DMEM supplemented with $10 \%$ FBS. Cells were maintained in a humid incubator $\left(37^{\circ} \mathrm{C}, 5 \% \mathrm{CO}_{2}\right)$.

To isolate primary neurons, CD-1 mice were purchased from Charles River Laboratories (Wilmington, MA, USA) and housed in the Animal Resource Center at Louisiana State University Health Sciences Center-Shreveport under specific pathogen-free conditions. All procedures were carried out in accordance with the guidelines of the Institutional Animal Care and Use Committee and were in compliance with the guidelines set forth by the Guide for the Care and Use of Laboratory Animals. Fetal mouse cerebral cortexes of 14-18 days of gestation were used. Briefly, the pregnant mice were anaesthetized with pentobarbital and embryos were removed by a cesarean section under sterile conditions. Cerebral cortexes were isolated under dissection microscope and washed with ice-cold $\mathrm{Ca}^{2+} / \mathrm{Mg}^{2+}$-free Hank's-buffered salt solution (HBSS) supplemented with $1 \%$ glucose and $50 \mu \mathrm{g} / \mathrm{ml}$ gentamicin. The isolated embryo cortexes were digested with papain solution [HBSS containing $500 \mu \mathrm{g} / \mathrm{ml}$ papain, $50 \mu \mathrm{g} /$ ml DNase1, $1 \%$ glucose, $10 \mu \mathrm{M} \mathrm{CaCl}, 5 \mathrm{mM}$ EDTA] for $15 \mathrm{~min}$ at $37^{\circ} \mathrm{C}$. Digested tissues were triturated into single cells using $1 \mathrm{ml}$ pipette in NEUROBASAL Media supplemented with 2\% B27 Supplement, $2 \mathrm{mM}$ glutamine, $1 \mathrm{mM}$ sodium pyruvate, $5 \mu \mathrm{g} / \mathrm{ml}$ insulin, and $40 \mu \mathrm{g} / \mathrm{ml}$ of gentamicin. Isolated cells were seeded at a density of $2 \times 10^{6}$ cells/well in a six-well plate coated with $10 \mu \mathrm{g} / \mathrm{ml}$ PDL in the above culture medium, and grown in a humid incubator $\left(37^{\circ} \mathrm{C}, 5 \%\right.$ $\mathrm{CO}_{2}$ ). Fresh medium was replaced every 3 days. The cells were used for experiments after 6 days of culture.

\section{Recombinant Adenoviral Constructs and Infection of Cells}

To generate recombinant adenoviruses expressing FLAGtagged wild-type (wt) mTOR, wt-mTOR was excised from 
expression vector PIRESNeo-FLAG-mTOR ${ }^{26}$ (gifts from Dr Jie Chen, University of Illinois, Urbana, IL, USA), and subcloned to pShuttle-CMV vector. The recombinant adenoviruses were generated and amplified using 'Ad-Easy system. ${ }^{27}$ Recombinant adenoviruses expressing HA-tagged constitutively active S6K1 (Ad-S6K1-ca) and the green fluorescence protein (GFP) (Ad-GFP) were generated and titrated, as described. ${ }^{28}$ Recombinant adenovirus encoding HA-tagged dominant negative AMPK $\alpha 1$ (Ad-dn-AMPK $\alpha)^{29}$ was a gift from Dr Nicholas JG Webster (University of California at San Diego, La Jolla, CA, USA). For experiments, PC12 cells were grown in the growth medium, and infected with the individual adenovirus for $24 \mathrm{~h}$ at 5 of multiplicity of infection $(\mathrm{MOI}=5)$. Subsequently, cells were used for experiments. Cells infected with Ad-GFP alone served as a control. Expression of HA-tagged S6K1-ca or dn-AMPK $\alpha$ was confirmed by western blot with antibodies to HA. As S6 ribosomal protein and ACC are the substrates for S6K1 and AMPK $\alpha$, the functions of S6K1-ca and dn-AMPK $\alpha$ in the cells were assessed by immunoblotting with antibodies to phospho-S6 ribosomal protein (Ser235/236) and phosphoACC (Ser79), respectively.

\section{Lentiviral shRNA Cloning, Production, and Infection}

To generate lentiviral shRNA to human AMPK $\alpha 1$, oligonucleotides containing the target sequences were synthesized, annealed, and inserted into FSIPPW lentiviral vector via the EcoR1/BamH1 restriction enzyme site. Oligonucleiotides used were: sense: $5^{\prime}$ AATTCCCGTTGTGGCTCACCCAACTATGCAAGAGATAGTT GGGTGAGCCACAACTTTTTG-3', anti-sense: 5'-GATCCAA AAAGTTGTGGCTCACCCAACTATCTCTTGCATAGTTGGGT GAGCCACAACGGG-3'. Lentiviral shRNA construct targeting GFP (control) was described. ${ }^{26}$ To produce lentiviral shRNAs, above constructs were co-transfected together with pMD2.G and psPAX2 (Addgene, Cambridge, MA, USA) to 293TD cells using Lipfectamine 2000 reagent (Invitrogen). Each virus-containing medium was collected 36 and $60 \mathrm{~h}$ post-transfection, respectively. For use, monolayer cells, when grown to about $70 \%$ confluence, were infected with above lentivirus-containing supernatant in the presence of $8 \mu \mathrm{g} / \mathrm{ml}$ polybrene for $12 \mathrm{~h}$ twice at an interval of $6 \mathrm{~h}$. Uninfected cells were eliminated by exposure to $2 \mu \mathrm{g} / \mathrm{ml}$ puromycin for $48 \mathrm{~h}$ before use.

\section{Assays for Cell Vability, Morphology, and Caspase-3/7 Activity}

PC12 cells, infected with Ad-mTOR, Ad-S6K1-ca, Ad-dnAMPK $\alpha$, or Ad-GFP (control), or infected with lentiviral shRNA to AMPK $\alpha 1$ or GFP, respectively, were seeded at a density of $1 \times 10^{4}$ cells/well in a flat-bottomed 96-well plate, precoated with PDL $(0.2 \mu \mathrm{g} / \mathrm{ml})$. Next day, cells were treated with/without $\mathrm{H}_{2} \mathrm{O}_{2}(0.5$ and $0.7 \mathrm{mM})$ for $24 \mathrm{~h}$ with six replicates of each treatment. After incubation, each well was added $20 \mu \mathrm{l}$ of one solution reagent (Promega) and incubated for $3 \mathrm{~h}$. Cell viability was determined by measuring the optical density (OD) at $490 \mathrm{~nm}$ using a Wallac 1420 Multi- label Counter (PerkinElmer Life Sciences, Wellesley, MA, USA). Caspase-3/7 activity was determined using Caspase-3/7 Assay Kit (AnaSpec, Fremont, CA, USA), following the instructions of the supplier. In addition, the cells were also seeded at a density of $5 \times 10^{5}$ cells/well in a PDL-coated sixwell plate. Next day, cells were exposed to $\mathrm{H}_{2} \mathrm{O}_{2}(0.5$ and $0.7 \mathrm{mM}$ ). After incubation for $24 \mathrm{~h}$, images were taken with an Olympus inverted phase-contrast microscope (Olympus Optical Co., Melville, NY, USA) $(200 \times)$ equipped with the Quick Imaging system.

\section{Western Blot Analysis}

After treatment, cells were briefly washed with cold PBS. On ice, cells were lysed in RIPA buffer [ $50 \mathrm{mM}$ Tris, $\mathrm{pH}$ 7.2; $150 \mathrm{mM} \mathrm{NaCl} ; 1 \%$ sodium deoxycholate; $0.1 \%$ SDS; $1 \%$ Triton-X $100 ; 10 \mathrm{mM} \mathrm{NaF} ; 1 \mathrm{mM} \mathrm{Na} \mathrm{VO}_{4}$; protease inhibitor cocktail (1:1000, Sigma). Lysates were sonicated for $10 \mathrm{~s}$ and centrifuged at $14000 \mathrm{rpm}$ for $10 \mathrm{~min}$ at $4^{\circ} \mathrm{C}$. Protein concentration was determined by bicinchoninic acid assay with bovine serum albumin as standard (Pierce). Equivalent amounts of protein were separated on $7.5-12 \%$ SDS-polyacrylamide gel and transferred to polyvinylidene difluoride membranes (Millipore, Bedford, MA, USA). Membranes were incubated with PBS containing 0.05\% Tween 20 and 5\% nonfat dry milk to block nonspecific binding and were incubated with primary antibodies, then with appropriate secondary antibodies conjugated to horseradish peroxidase. Immunoreactive bands were visualized by using enhanced chemiluminescence solution (Pierce). To check the amount of protein loaded, the immunoblots were treated with stripping solution $(62.5 \mathrm{mM}$ Tris buffer, $\mathrm{pH}$ 6.7, containing $2 \%$ SDS and $100 \mathrm{mM} \beta$-mercaptoethanol) for $30 \mathrm{~min}$ at $50^{\circ} \mathrm{C}$ and incubated with mouse monoclonal anti- $\beta$-tubulin antibody (Sigma) followed by horseradish peroxidase-coupled goat anti-mouse IgG (Pierce).

\section{Detection of Phosphorylation of IGFR}

PC12 cells $\left(5 \times 10^{5} / \mathrm{ml}\right)$ were seeded in $100-\mathrm{mm}$ dishes, precoated with PDL $(0.2 \mu \mathrm{g} / \mathrm{ml})$. The next day, cells were treated with $\mathrm{H}_{2} \mathrm{O}_{2}(0-1 \mathrm{mM})$, or were treated with/without $\mathrm{H}_{2} \mathrm{O}_{2}(0.5$ and $0.7 \mathrm{mM})$ following $1 \mathrm{~h}$ of NAC $(5 \mathrm{mM})$ preincubation. After incubation for $2 \mathrm{~h}$, cells were washed once in ice-cold $1 \times$ PBS, followed by lysis in RIPA buffer. After clearing via centrifugation $\left(14000 \mathrm{rpm}, 15 \mathrm{~min}, 4^{\circ} \mathrm{C}\right), 500 \mu \mathrm{l}$ supernatants of cell lysates were collected and incubated overnight at $4^{\circ} \mathrm{C}$ with $1 \mu \mathrm{g}$ of antibody to IGFR $\beta$ and $30 \mu \mathrm{l}$ of protein A/G-agarose beads (Santa Cruz Biotechnology). Immunoprecipitates were washed with RIPA buffer two times and twice with ice-cold PBS, followed by immunoblotting with antibodies to $\mathrm{p}$-Tyr and IGFR $\beta$, respectively. IgG-heavy chain and light chain from each immunoprecipitated sample were used for loading control.

\section{Statistical Analysis}

Results were expressed as mean values \pm standard error (mean \pm s.e.). Statistical analysis was performed by Student's 
$t$-test (STATISTICA, Statsoft Inc, Tulsa, OK). A level of $P<0.05$ was considered to be significant.

\section{RESULTS}

\section{Hydrogen Peroxide Induction of ROS Inhibits mTOR-Mediated Phosphorylation of S6K1 and 4E-BP1 in Neuronal Cells}

We have shown that $\mathrm{H}_{2} \mathrm{O}_{2}$ induces apoptosis of neuronal cells. ${ }^{9}$ mTOR is a central regulator of cell survival. ${ }^{10}$ To determine whether $\mathrm{H}_{2} \mathrm{O}_{2}$ induction of neuronal cell death is associated with inhibition of mTOR signaling, PC12 cells and primary murine neurons were used. By western blotting analysis, we found that treatment of cells with different concentrations of $\mathrm{H}_{2} \mathrm{O}_{2}(0-2 \mathrm{mM})$ for $2 \mathrm{~h}$ decreased phosphorylation of mTOR, S6K1, and 4E-BP1 in a concentrationdependent manner, and at concentrations of $>0.5 \mathrm{mM}$ (for
PC12) or $>1 \mathrm{mM}$ (for neurons), $\mathrm{H}_{2} \mathrm{O}_{2}$ dramatically reduced or completely blocked phosphorylation of S6K1 or the substrate of S6K1, S6, as well as 4E-BP1 (Figure 1a). We also observed that $\mathrm{H}_{2} \mathrm{O}_{2}$ inhibited phosphorylation of $\mathrm{S} 6 \mathrm{~K} 1$ and 4E-BP1 in a time-dependent manner. As shown in Figure 1b, at 15-min post-experiment, $\mathrm{H}_{2} \mathrm{O}_{2}$ obviously reduced phosphorylation of S6K1 and 4E-BP1, and such effect was sustained for over $2 \mathrm{~h}$. We also noticed that a complete abolishment occurred at $30 \mathrm{~min}$ (for PC12) or at $120 \mathrm{~min}$ (for neurons) post-exposure to $\mathrm{H}_{2} \mathrm{O}_{2} \cdot \mathrm{H}_{2} \mathrm{O}_{2}$ did not markedly alter total protein levels of those proteins (Figure 1a and b). It should be mentioned that a considerable basal level of phosphorylation of 4E-BP1 was detected (Figure 1a and b) in PC12 cells and primary murine neurons. Phosphorylation state of 4E-BP1 was initially detected with an antibody to 4EBP1. Phosphorylation of 4E-BP1 decreases its electrophoretic
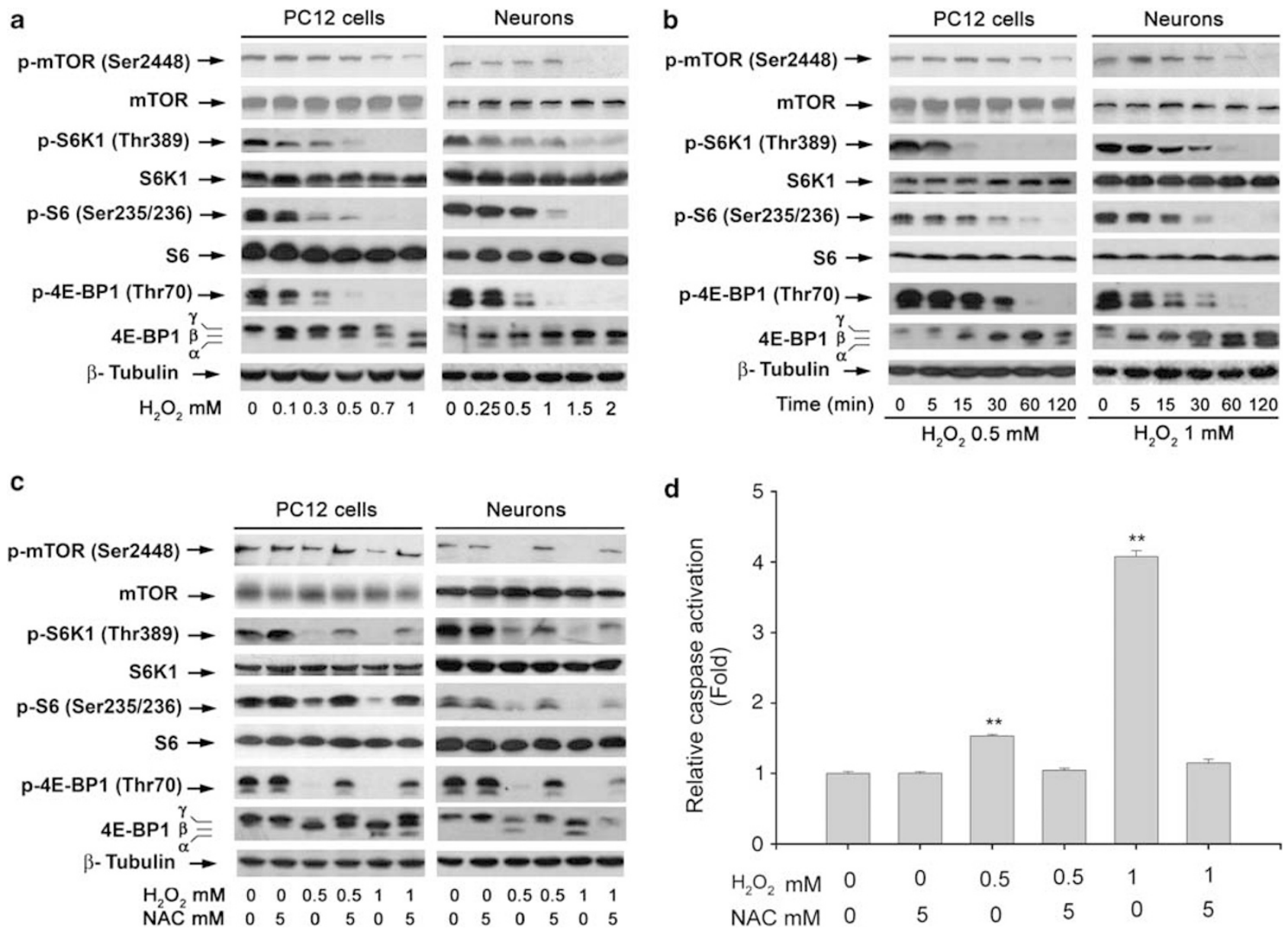

Figure 1 Hydrogen peroxide induction of ROS inhibits phosphorylation of mTOR-mediated S6K1 and 4E-BP1 in neuronal cells. (a) PC12 cells and primary neurons were treated with $0-2 \mathrm{mM} \mathrm{H}_{2} \mathrm{O}_{2}$ for $2 \mathrm{~h}$, (b) treated with $0.5-1 \mathrm{mM} \mathrm{H}_{2} \mathrm{O}_{2}$ for indicated time (0-120 min), or (c) with 0.5 and $1 \mathrm{mM} \mathrm{H} \mathrm{O}_{2}$ for $2 \mathrm{~h}$ after pretreatment with NAC $(5 \mathrm{mM})$ for $1 \mathrm{~h}$. Total cell lysates were subjected to western blot analysis using indicated antibodies. The blots were probed for $\beta$-tubulin as a loading control. Similar results were observed in at least three independent experiments. $\mathrm{H}_{2} \mathrm{O}_{2}$ markedly decreased phosphorylation of S6K1 and 4E-BP1 in a concentration-dependent (a) and time-dependent (b) manner, which was attenuated by NAC (c). (d) PC12 cells, seeded in 96-well plates (black wall), were exposed to 0.5 and $1 \mathrm{mM} \mathrm{H}_{2} \mathrm{O}_{2}$ for $24 \mathrm{~h}$ after pretreatment with $\mathrm{NAC}(5 \mathrm{mM})$ for $1 \mathrm{~h}$. Subsequently, $50 \mu$ l of caspase-3/7 substrate solution was added into each well. After incubation on a plate shaker at $100 \mathrm{rpm}$ at room temperature for $1 \mathrm{~h}$ (avoiding direct light), the fluorescence intensity was measured at $\mathrm{Ex} / \mathrm{Em}=354 \mathrm{~nm} / 422 \mathrm{~nm}$, using a Wallac 1420 Multilabel Counter. Results are presented as mean \pm s.e. $(n=6)$. ${ }^{* * P}<0.01$, difference vs control group $\left(\mathrm{H}_{2} \mathrm{O}_{2}=0 \mathrm{mM}\right.$, and $\left.\mathrm{NAC}=0 \mathrm{mM}\right)$. 
mobility during SDS-polyacrylamide gel electrophoresis. ${ }^{30}$ $\mathrm{H}_{2} \mathrm{O}_{2}$ also decreased phosphorylation of $4 \mathrm{E}-\mathrm{BP} 1$ in a concentration- and time-dependent manner, as indicated by the decrease in the intensity of the uppermost band $\gamma$ and by the increase in the higher mobility band $\alpha$ and $\beta$ that corresponds to a less phosphorylated form of 4E-BP1 (Figure 1a and $b$ ). We also verified the finding using the antibodies against to phospho-4E-BP1 (Thr70) (Figure 1a and b). The findings indicate that $\mathrm{H}_{2} \mathrm{O}_{2}$ inhibits mTOR-mediated S6K1 and $4 \mathrm{E}-\mathrm{BP} 1$ signaling pathways in the neuronal cells.

To unveil whether $\mathrm{H}_{2} \mathrm{O}_{2}$ inhibition of mTOR signaling is due to induction of ROS, $\mathrm{PC} 12$ cells were exposed to $\mathrm{H}_{2} \mathrm{O}_{2}$ ( 0.5 and $1 \mathrm{mM}$ ) for $2 \mathrm{~h}$ after pretreatment with $\mathrm{NAC}$, a ROS scavenger, for $1 \mathrm{~h}$. As shown in Figure 1c, $\mathrm{H}_{2} \mathrm{O}_{2}$ inhibited phosphorylation of mTOR, S6K1 and 4E-BP1, which was remarkably attenuated by NAC. Similar data were seen in primary neurons (Figure 1c). In addition, consistent with our earlier findings, ${ }^{9}$ we also found that NAC blocked $\mathrm{H}_{2} \mathrm{O}_{2}$ inhibition of cell viability, induction of cell roundup (data not shown), and activation of caspases $3 / 7$ in PC12 cells (Figure 1d), suggesting that NAC prevented $\mathrm{H}_{2} \mathrm{O}_{2^{-}}$ induced apoptosis of the cells (Figure 1d). The findings support the notion that $\mathrm{H}_{2} \mathrm{O}_{2}$ induces ROS contributing to suppression of mTOR-mediated S6K1 and 4E-BP1 pathways, leading to neuronal cell death.

\section{Ectopic Expression of Wild-Type mTOR or Constitutively Active S6K1, or Downregulation of 4E-BP1 Partially Prevents Hydrogen Peroxide-Induced Neuronal Cell Death}

To further assess the role of mTOR in $\mathrm{H}_{2} \mathrm{O}_{2}$-induced neuronal cell death, PC12 cells were infected with Ad-mTOR and Ad-GFP (control), respectively. Ectopic expression of FLAG-tagged wt-mTOR conferred considerable resistance to $\mathrm{H}_{2} \mathrm{O}_{2}$ inhibition of mTOR-mediated phosphorylation of $\mathrm{S} 6 \mathrm{~K} 1$ and $4 \mathrm{E}-\mathrm{BP} 1$ (Figure 2a), as well as $\mathrm{H}_{2} \mathrm{O}_{2}$ induced cell death (Figure 2b), suggesting that $\mathrm{H}_{2} \mathrm{O}_{2}$-induced apoptosis is at least partially associated with inhibition of mTOR.

mTOR-mediated S6K1 and 4E-BP1 pathways are critical for cell survival. ${ }^{10}$ To evaluate the role of $\mathrm{S} 6 \mathrm{~K} 1$ pathway in $\mathrm{H}_{2} \mathrm{O}_{2}$ induction of neuronal cell death, PC12 cells were infected with recombinant adenoviruses expressing HAtagged constitutively active S6K1 (Ad-S6K1-ca) or control virus encoding GFP alone. As shown in Figure 3a, expression of high levels of recombinant S6K1-ca was observed in the cells infected with Ad-S6K1-ca, but not in those infected with Ad-GFP, as detected by immunoblotting with antibodies to HA and S6K1. The basal level of phosphorylation of S6 ribosomal protein, a substrate of S6K1, was considerably high in the cells, which was not enhanced by expression of S6K1ca. However, when the cells were exposed to $\mathrm{H}_{2} \mathrm{O}_{2}(0.5$ and $0.7 \mathrm{mM}$ ) for $2 \mathrm{~h}$, expression of S6K1-ca obviously rendered resistance to $\mathrm{H}_{2} \mathrm{O}_{2}$ inhibition of phosphorylation of $\mathrm{S} 6 \mathrm{~K} 1$ and $\mathrm{S} 6$ ribosomal protein. Of interest, expression of S6K1-ca also significantly increased cell viability in the presence of $\mathrm{H}_{2} \mathrm{O}_{2}$ (Figure $3 \mathrm{~b}$ ) or prevented $\mathrm{H}_{2} \mathrm{O}_{2}$-induced neuronal apoptosis (Figure 3c).

Next, we assessed the role of $4 \mathrm{E}-\mathrm{BP} 1$ pathway in $\mathrm{H}_{2} \mathrm{O}_{2}$ induction of neuronal cell death. As 4E-BP1 functions as a suppressor of eIF4E, ${ }^{10}$ downregulation of $4 \mathrm{E}-\mathrm{BP} 1$ would lead to loss of suppression of eIF4E. For this, 4E-BP1 was downregulated by $>90 \%$ in PC12 cells using lentiviral a

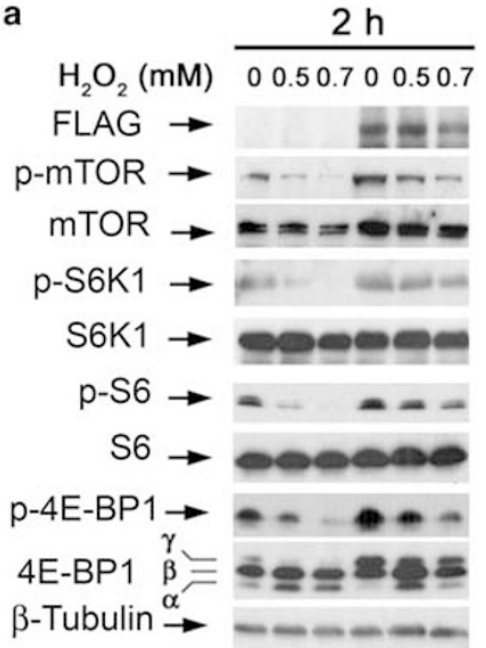

Ad-GFP $+++\cdots$

Ad-mTOR - - - + + +

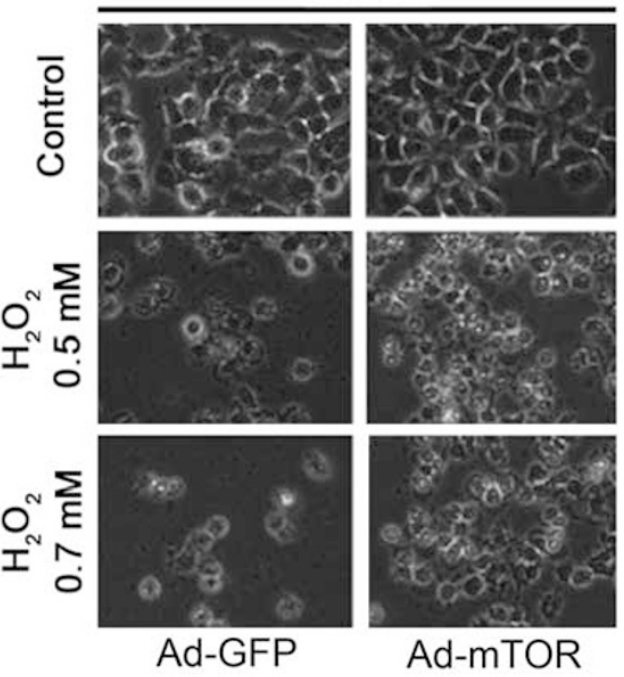

Figure 2 Expression of wt-mTOR partially prevents hydrogen peroxide inhibition of mTOR signaling and cell death. (a) PC12 cells, infected with replicationdefective adenoviral recombinant expressing FLAG-tagged wt-mTOR (Ad-mTOR) or the control adenovirus (Ad-GFP), were exposed to $\mathrm{H}_{2} \mathrm{O}_{2}(0.5$ and $0.7 \mathrm{mM}$ ) for $2 \mathrm{~h}$, followed by western blot analysis using indicated antibodies. The blots were probed for $\beta$-tubulin as a loading control. Similar results were observed in at least three independent experiments. (b) PC12 cells, infected with Ad-GFP or Ad-mTOR, were exposed to $\mathrm{H}_{2} \mathrm{O}_{2}(0.5$ and $0.7 \mathrm{mM}$ ) for $24 \mathrm{~h}$, followed by morphological analysis using an Olympus inverted phase-contrast microscope $(200 \times)$ equipped with Quick Imaging system. 

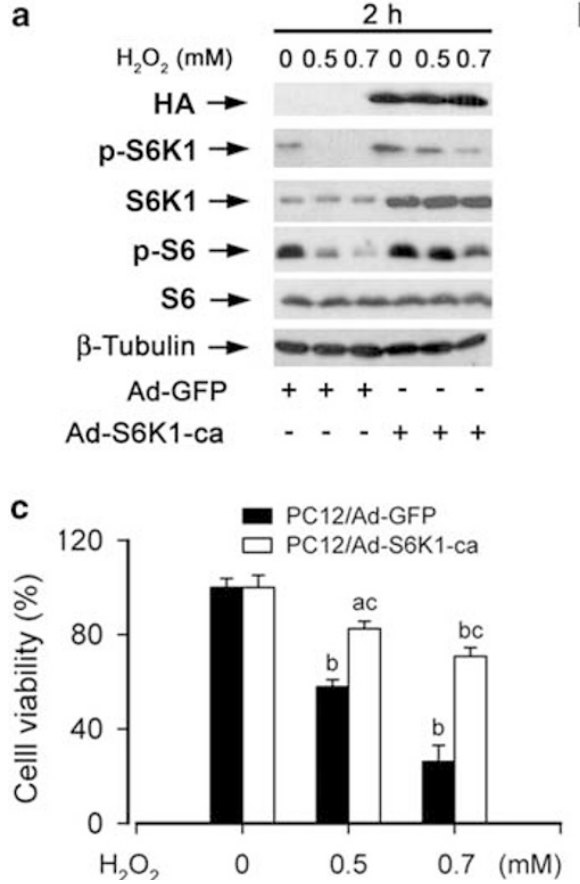

b

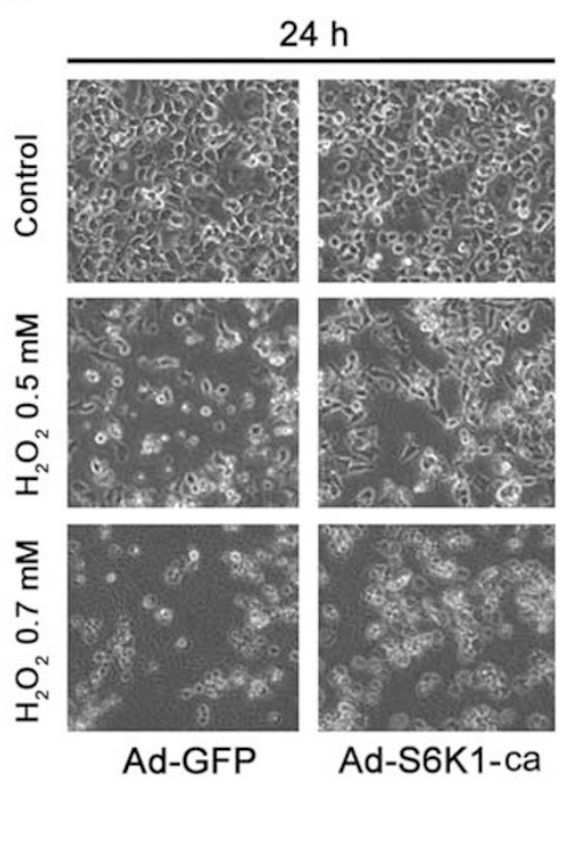

Figure 3 Expression of constitutively active S6K1 partially prevents hydrogen peroxide inhibition of S6K1 pathway and cell viability. (a) PC12 cells, infected with replication-defective adenoviral recombinant expressing constitutively active S6K1 (Ad-S6K1-ca) or the control adenovirus (Ad-GFP), were exposed to $\mathrm{H}_{2} \mathrm{O}_{2}(0.5$ and $0.7 \mathrm{mM})$ for $2 \mathrm{~h}$, followed by western blot analysis using indicated antibodies. The blots were probed for $\beta$-tubulin as a loading control. Similar results were observed in at least three independent experiments. (b and c) PC12 cells, infected with Ad-GFP or Ad-S6K1-ca, were exposed to $\mathrm{H}_{2} \mathrm{O}_{2}$ ( 0.5 and $0.7 \mathrm{mM}$ ) for $24 \mathrm{~h}$, followed by (b) morphological analysis using an Olympus inverted phase-contrast microscope $(200 \times)$ equipped with Quick Imaging system, and (c) cell viability assay using one solution reagent, respectively. Results are presented as mean \pm s.e. $(n=6)$. ${ }^{\mathrm{a}} P<0.05$, ${ }^{\mathrm{b}} P<0.01$, difference $v s$ control group; ${ }^{C} P<0.01$, Ad-S6K1-ca group vs Ad-GFP group. PC12 cells infected with an adenovirus expressing constitutively active S6K1 (Ad-S6K1-ca), but not a control virus (Ad-GFP), conferred partial resistance to $\mathrm{H}_{2} \mathrm{O}_{2}$ inhibition of phosphorylation of $\mathrm{S} 6$ ribosomal protein (a), as well as cell viability (b and c).

a
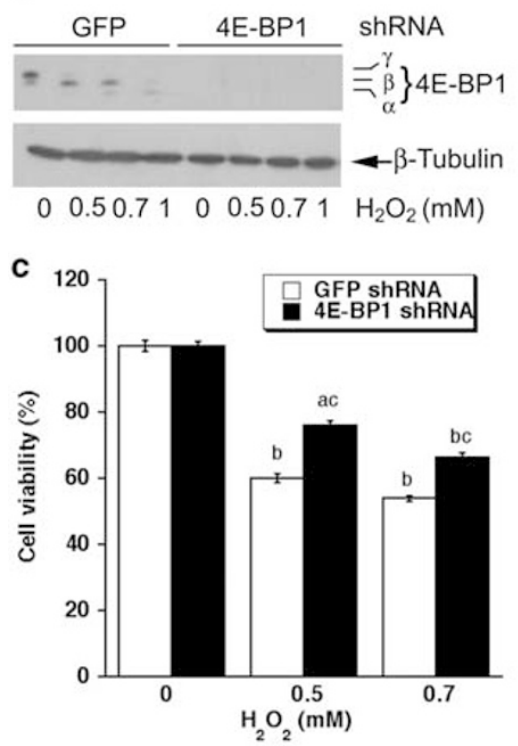

b

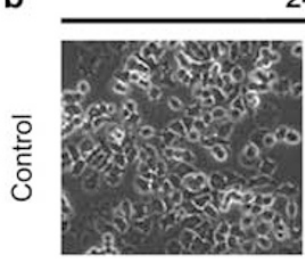

$24 \mathrm{~h}$
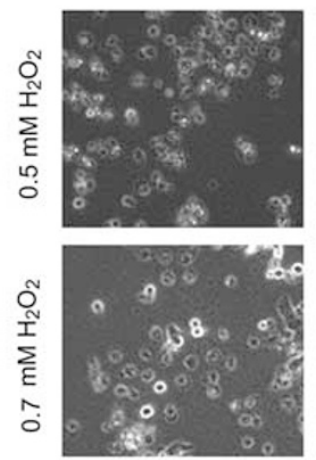

GFP ShRNA
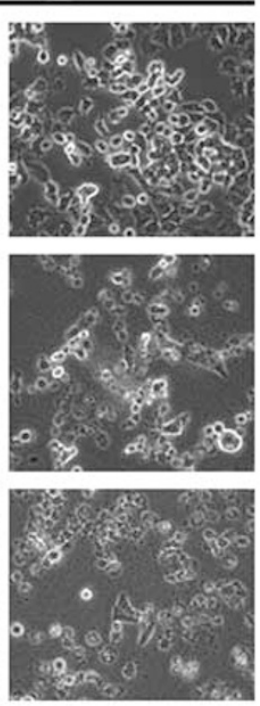

4E-BP1 ShRNA

Figure 4 Downregulation of 4E-BP1 partially rescues hydrogen peroxide-induced neuronal cell death. (a) PC12 cells, infected with lentiviral shRNAs to 4EBP1 and GFP (as control), were exposed to $\mathrm{H}_{2} \mathrm{O}_{2}(0.5,0.7$, and $1 \mathrm{mM}$ ) for $2 \mathrm{~h}$, followed by western blot analysis with antibodies to $4 \mathrm{E}-\mathrm{BP} 1$. The blots were probed for $\beta$-tubulin as a loading control. Similar results were observed in at least three independent experiments. (b and c) Morphology and cell viability of lentiviral shRNA-infected PC12 cells, treated with/without $\mathrm{H}_{2} \mathrm{O}_{2}(0.5$ and $0.7 \mathrm{mM})$ for $24 \mathrm{~h}$, were assessed using an Olympus inverted phase-contrast microscope $(200 \times)$ equipped with Quick Imaging system, and using one solution assay, respectively. Results are presented as mean \pm s.e. $n=6$. ${ }^{\mathrm{a}} P<0.05,{ }^{\mathrm{b}} P<0.01$, difference vs control group; ${ }^{\mathrm{C}} P<0.01,4 \mathrm{E}-\mathrm{BP} 1$ shRNA group vs GFP shRNA group. 

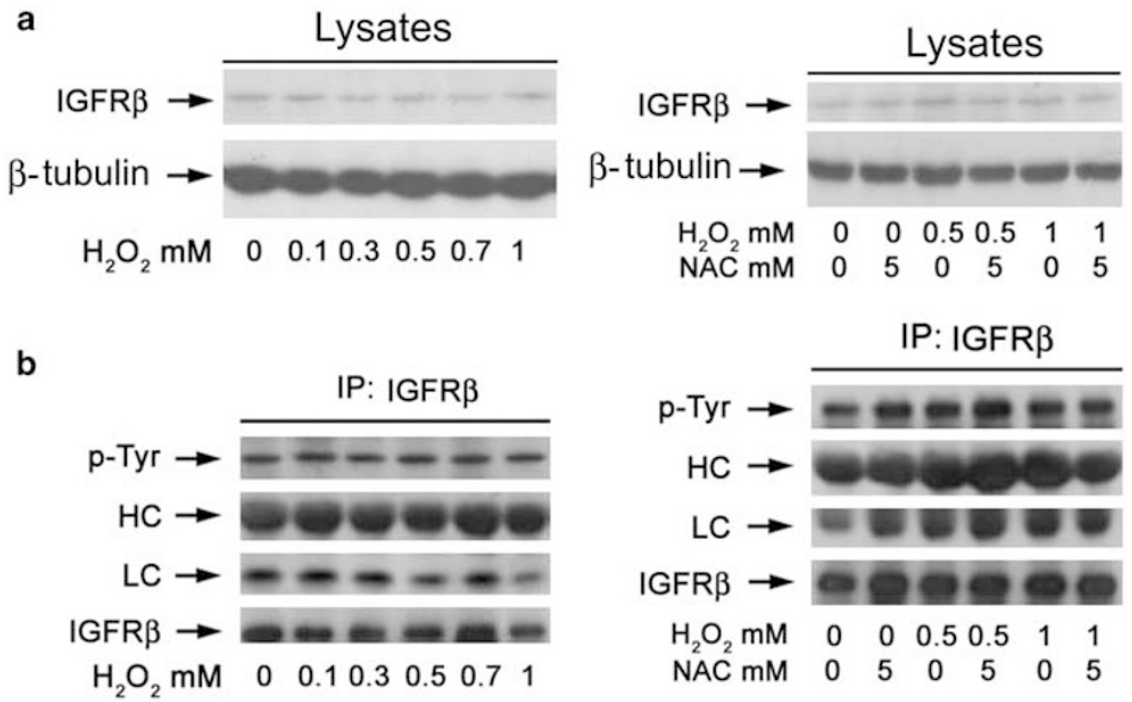

Figure 5 Hydrogen peroxide does not alter protein expression and phosphorylation of IGFR in neuronal cells. PC12 cells were treated with 0-1 mM $\mathrm{H}_{2} \mathrm{O}_{2}$ for $2 \mathrm{~h}$, or with 0.5 and $0.7 \mathrm{mM} \mathrm{H}_{2} \mathrm{O}_{2}$ for $2 \mathrm{~h}$ after pretreatment with NAC $(5 \mathrm{mM})$ for $1 \mathrm{~h}$, followed by (a) western blot analysis with indicated antibodies, or (b) immunoprecipitation with antibodies to IGFR $\beta$ subunit (IGFR $\beta$ ) plus A/G-agarose, and immunoblotting with antibodies to phosphotyrosine ( $p$-Tyr) and IGFR $\beta$, respectively. HC, heavy chain of IgG; LC, light chain of IgG.
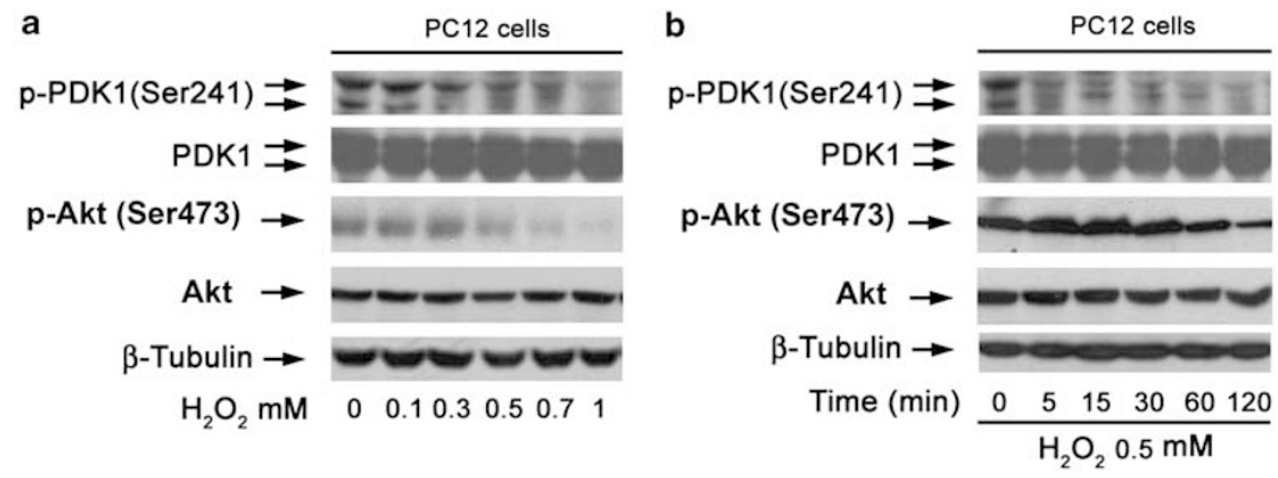

C

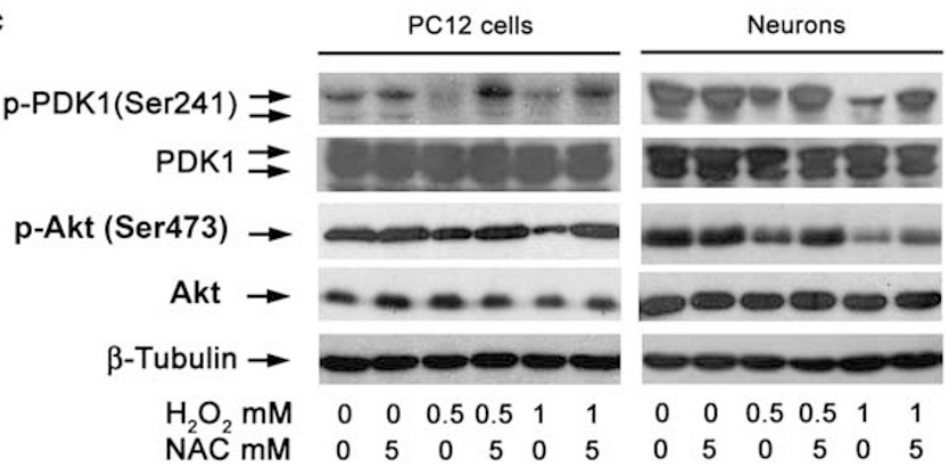

Figure 6 Hydrogen peroxide inhibits Akt and PDK1 phosphorylation in neuronal cells. (a) PC12 cells were treated with $0-1 \mathrm{mM} \mathrm{H}_{2} \mathrm{O}_{2}$ for $2 \mathrm{~h}$, or (b) with $0.5 \mathrm{mM} \mathrm{H}_{2} \mathrm{O}_{2}$ for $0-120 \mathrm{~min}$. Total lysates were subjected to western blot analysis using indicated antibodies. The blots were probed for $\beta$-tubulin as a loading control. Similar results were observed in at least three independent experiments. $\mathrm{H}_{2} \mathrm{O}_{2}$ inhibited phosphorylation of Akt and PDK1 in a concentration-dependent (a) and time-dependent (b) manner. (c) PC12 cells and primary neurons were pretreated with treated with/without NAC $(5 \mathrm{mM})$ for $1 \mathrm{~h}$, and then incubated with/without $\mathrm{H}_{2} \mathrm{O}_{2}$ at indicated concentrations for $2 \mathrm{~h}$, followed by western blot analysis using indicated antibodies. NAC markedly reversed $\mathrm{H}_{2} \mathrm{O}_{2}$ inhibition of Akt or PDK1 activity.

shRNA to 4E-BP1 (Figure 4a). Downregulation of 4E-BP1 significantly increased cell viability in the presence of $\mathrm{H}_{2} \mathrm{O}_{2}$ (0.5 and $0.7 \mathrm{mM}$ ) (Figure $4 \mathrm{~b}$ and c). Collectively, our results indicate that $\mathrm{H}_{2} \mathrm{O}_{2}$ induced neuronal cell death at least in part through inhibition of mTOR-mediated S6K1 and 4E-BP1/eIF4E pathways. 


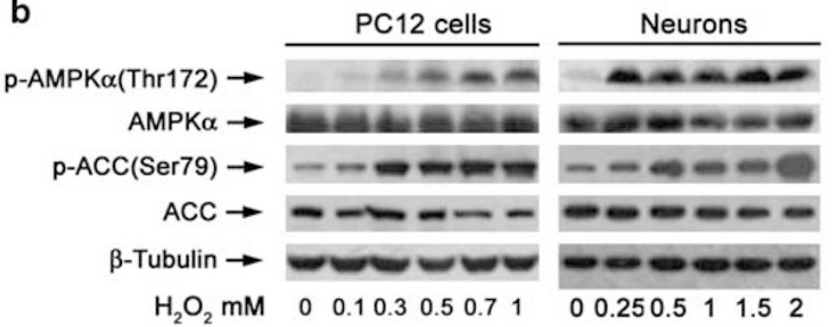

C

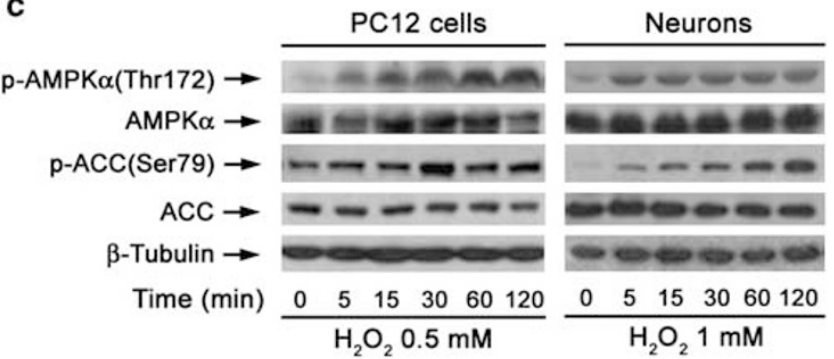

d

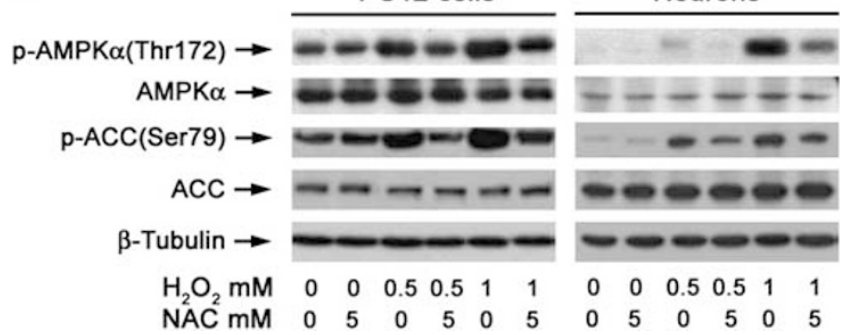

Figure 7 Hydrogen peroxide induction of ROS activates AMPK signaling in neuronal cells. (a) PC12 cells were treated with 0-1 $\mathrm{mM} \mathrm{H}_{2} \mathrm{O}_{2}$ for $2 \mathrm{~h}$, (b) $\mathrm{PC} 12$ cells and primary neurons were treated with $0-2 \mathrm{mM} \mathrm{H}_{2} \mathrm{O}_{2}$ for $2 \mathrm{~h}$, (c) or treated with $0.5-1 \mathrm{mM} \mathrm{H}_{2} \mathrm{O}_{2}$ for indicated time (0-120 min), or (d) with 0.5 and $0.7 \mathrm{mM} \mathrm{H}_{2} \mathrm{O}_{2}$ for $2 \mathrm{~h}$ after pretreatment with $\mathrm{NAC}(5 \mathrm{mM})$ for $1 \mathrm{~h}$. Total cell lysates were subjected to western blot analysis using indicated antibodies. The blots were probed for $\beta$-tubulin as a loading control. Similar results were observed in at least three independent experiments. $\mathrm{H}_{2} \mathrm{O}_{2}$ obviously increased phosphorylation of AMPK $\alpha$ as well as its substrate $(A C C)$ in a concentration-dependent (b) and timedependent (c) manner, which was remarkably blocked by NAC (d).

\section{Hydrogen Peroxide Inhibits Phosphorylation of PDK1 and Akt, but not IGFR, in Neuronal Cells}

IGFR, a transmembrane protein tyrosine kinase, lies upstream of mTOR. ${ }^{10}$ To determine whether $\mathrm{H}_{2} \mathrm{O}_{2}$ induction of ROS inhibits mTOR signaling by suppressing the activity of IGFR, PC12 cells were treated with $\mathrm{H}_{2} \mathrm{O}_{2}(0-1 \mathrm{mM})$ for $2 \mathrm{~h}$, or exposed to $\mathrm{H}_{2} \mathrm{O}_{2}(0.5$ and $1 \mathrm{mM})$ for $2 \mathrm{~h}$ following $1 \mathrm{~h}$ of NAC $(5 \mathrm{mM})$ pretreatment, followed by immunoprecipita- tion with antibodies to $\operatorname{IGFR} \beta$ subunit $(\operatorname{IGFR} \beta)$, and immunoblotting with antibodies to phosphotyrosine (p-Tyr) and IGFR $\beta$, respectively. We found that treatment with $\mathrm{H}_{2} \mathrm{O}_{2}$ or NAC did not obviously impact protein expression of IGFR $\beta$ (Figure 5a). Furthermore, $\mathrm{H}_{2} \mathrm{O}_{2}$ failed to alter the basal or NAC-pretreated tyrosine phosphorylaiton of IGFR $\beta$, indicating that $\mathrm{H}_{2} \mathrm{O}_{2}$ did not affect IGFR activity (Figure 5b).

As activated Akt and PDK1 may positively regulate mTOR and S6K1, respectively, ${ }^{10}$ we next investigated whether $\mathrm{H}_{2} \mathrm{O}_{2}$ induction of ROS inhibits mTOR-mediated phosphorylation of mTOR and S6K1 by suppressing the activity of Akt and PDK1, respectively. To this end, PC12 cells were treated with different concentrations of $\mathrm{H}_{2} \mathrm{O}_{2}(0-1 \mathrm{mM})$ for $2 \mathrm{~h}$, or with $0.5 \mathrm{mM} \mathrm{H}_{2} \mathrm{O}_{2}$ for $0-2 \mathrm{~h}$. We found that a concentrationdependent decrease of phosphorylation of Akt and PDK1 was detected by western blot analysis, although $\mathrm{H}_{2} \mathrm{O}_{2}$ did not alter cellular protein levels of Akt and PDK1 (Figure 6a). $\mathrm{H}_{2} \mathrm{O}_{2}$ inhibited phosphorylation of PDK1 in a time-dependent manner. However, $\mathrm{H}_{2} \mathrm{O}_{2}$ transiently activated Akt within 5-30 min, and then inhibited phosphorylation of Akt in 1-2 h (Figure 6b). Treatment with NAC markedly prevented $\mathrm{H}_{2} \mathrm{O}_{2}$ inhibition of Akt and PDK1 phosphorylation in PC12 cells (Figure 6c). Similar results were also observed in primary neurons (Figure $6 \mathrm{c}$ ), indicating that $\mathrm{H}_{2} \mathrm{O}_{2}$ induction of ROS inhibits Akt and PDK1 activity.

\section{Hydrogen Peroxide Induction of ROS Activates AMPK, but not PTEN}

PTEN and AMPK are two major negative regulators of mTOR signaling. ${ }^{10,23}$ To determine whether $\mathrm{H}_{2} \mathrm{O}_{2}$ inhibition of mTOR signaling is associated with activation of PTEN and/or AMPK, PC12 cells were exposed to $0-1 \mathrm{mM} \mathrm{H}_{2} \mathrm{O}_{2}$ for $2 \mathrm{~h}$ or to $0.5 \mathrm{mM} \mathrm{H}_{2} \mathrm{O}_{2}$ for different time (0-120 min). Our western blot analysis revealed that exposure to $\mathrm{H}_{2} \mathrm{O}_{2}$ did not obviously alter protein expression and phosphorylation of PTEN (Figure 7a). However, $\mathrm{H}_{2} \mathrm{O}_{2}$ increased phosphorylation of AMPK $\alpha$ and its substrate (ACC) in a concentrationand time-dependent manner, although there was no effect on cellular protein expression of AMPK $\alpha$ (Figure $7 \mathrm{~b}$ and c). Similar data were observed in primary neurons (Figure $7 \mathrm{~b}$ and $\mathrm{c}$ ).

Next, we tested whether $\mathrm{H}_{2} \mathrm{O}_{2}$ activation of AMPK $\alpha$ is related to ROS induction. By western blot analysis, we found that pretreatment with NAC markedly attenuated $\mathrm{H}_{2} \mathrm{O}_{2}$ increase of phosphorylation of AMPK $\alpha$ and ACC in PC12 cells and primary neurons (Figure $7 \mathrm{~d}$ ). Our findings suggest that $\mathrm{H}_{2} \mathrm{O}_{2}$-induced oxidative stress activates AMPK $\alpha$ signaling.

\section{Expression of Dominant Negative AMPK $\alpha$ or Downregulation of AMPK $\alpha 1$ Partially Prevents Hydrogen Peroxide Inhibition of mTOR-Mediated Phosphorylation of S6K1 and 4E-BP1, as well as Neuronal Cell Death}

To further determine whether $\mathrm{H}_{2} \mathrm{O}_{2}$ activation of AMPK $\alpha$ is correlated with its inhibition of mTOR-mediated phosphorylation of S6K1 and 4E-BP1, PC12 cells, infected with Ad-dnAMPK $\alpha$ and Ad-GFP (as control), were exposed to $\mathrm{H}_{2} \mathrm{O}_{2}(0.5$ 

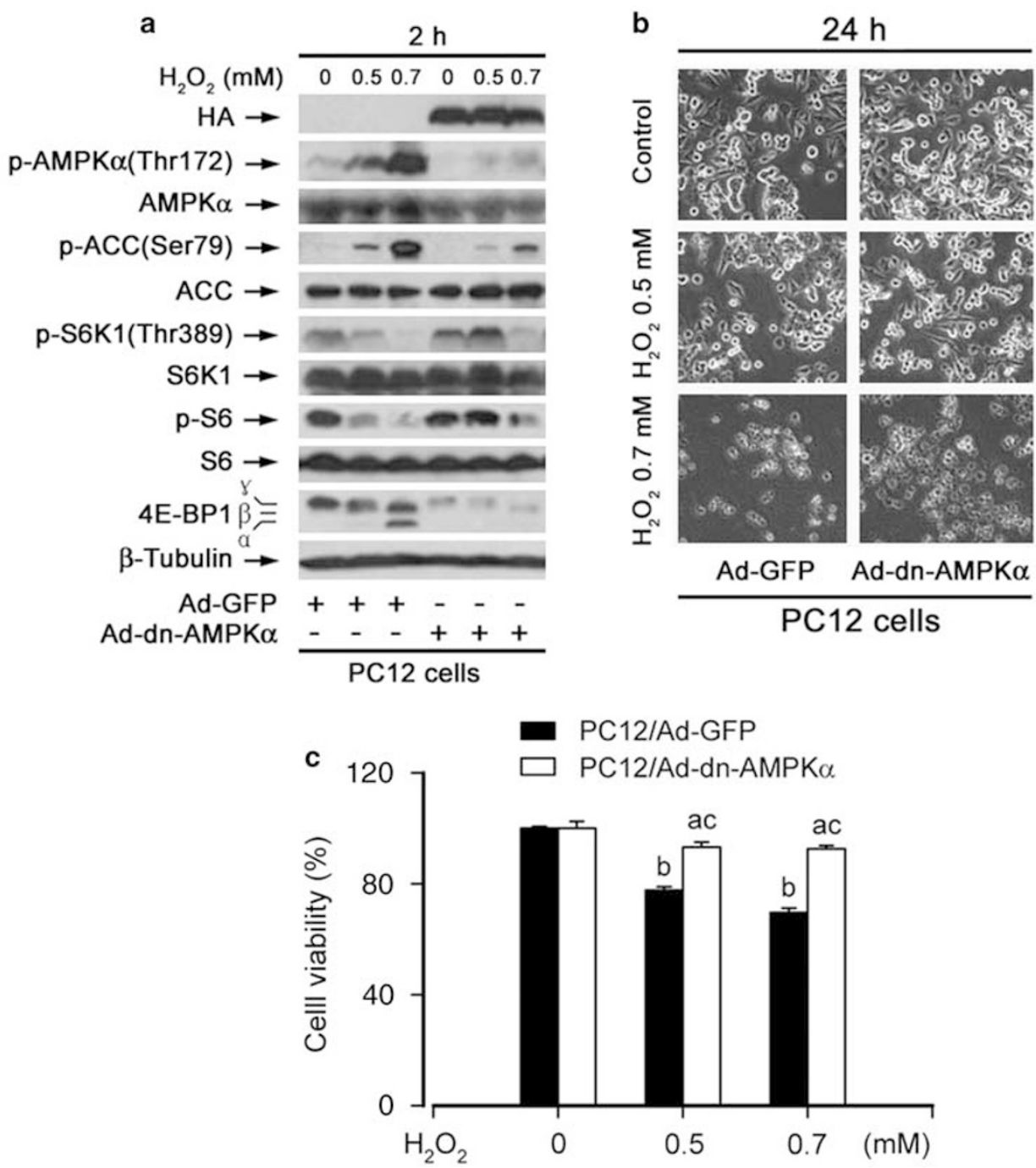

Figure 8 Expression of a dominant negative AMPK $\alpha$ partially prevents hydrogen peroxide inhibition of phosphorylation of S6K1 and 4E-BP1, as well as cell viability. (a) PC12 cells, infected with Ad-dn-AMPK $\alpha$ and Ad-GFP (as control), were exposed to $\mathrm{H}_{2} \mathrm{O}_{2}(0.5$ and $0.7 \mathrm{mM})$ for $2 \mathrm{~h}$, followed by western blot analysis using indicated antibodies. The blots were probed for $\beta$-tubulin as a loading control. Similar results were observed in at least three independent experiments. (b and c) PC12 cells, infected with Ad-dn-AMPK $\alpha$ and Ad-GFP (as control), were exposed to $\mathrm{H}_{2} \mathrm{O}_{2}(0.5$ and $0.7 \mathrm{mM})$ for $24 \mathrm{~h}$, followed by (b) morphological analysis using an Olympus inverted phase-contrast microscope $(200 \times)$ equipped with Quick Imaging system, and (c) cell viability assay using one solution reagent, respectively. Results are presented as mean \pm s.e. $(n=6)$. ${ }^{\mathrm{a}} P<0.05,{ }^{\mathrm{b}} P<0.01$, difference $v s$ control group; ${ }^{\mathrm{C}} P<0.01$, Ad-dn-AMPK $\alpha$ group vs. Ad-GFP group. Overexpression of a dominant negative AMPK $\alpha$ partially rescued cells from death induced by $\mathrm{H}_{2} \mathrm{O}_{2}$, by inhibiting phosphorylation of AMPK $\alpha$ and ACC and increasing phosphorylations of mTOR-mediated S6K1, S6, and 4E-BP1.

and $0.7 \mathrm{mM}$ ) for $2 \mathrm{~h}$. Western blot analysis revealed that ectopic expression of dn-AMPK $\alpha$ obviously blocked $\mathrm{H}_{2} \mathrm{O}_{2}$ induced phosphorylation of AMPK $\alpha$ and its substrate, ACC (Figure 8a). Consistently, $\mathrm{H}_{2} \mathrm{O}_{2}$ inhibition of phosphorylation of S6K1, S6, and 4E-BP1 was apparently attenuated by expression of dn-AMPK $\alpha$ (Figure 8a). Furthermore, our morphological analysis and cell viability assay revealed that expression of dn-AMPK $\alpha$ also partially protected PC12 cells from apoptosis induced by $\mathrm{H}_{2} \mathrm{O}_{2}$ (Figure $8 \mathrm{~b}$ and c). Therefore, our results suggest that $\mathrm{H}_{2} \mathrm{O}_{2}$ induces apoptosis of the neuronal cells at least in part through activation of AMPK $\alpha$, leading to inhibition of mTOR-mediated phosphorylation of S6K1 and 4E-BP1.
To further show the role of AMPK in $\mathrm{H}_{2} \mathrm{O}_{2}$ inhibition of mTOR signaling and induction of neuronal cell death, expression of AMPK $\alpha 1$ was silenced by RNA interference. As shown in Figure 9a, lentiviral shRNA to AMPK $\alpha 1$, but not to GFP, downregulated AMPK $\alpha 1$ expression by $\sim 85 \%$ in SH-SY5Y cells. Downregulation of AMPK $\alpha 1$ decreased the basal level of phosphorylation of ACC but increased the basal level of phosphorylation of mTOR. Of importance, silencing expression of AMPK $\alpha 1$ obviously attenuated $\mathrm{H}_{2} \mathrm{O}_{2}$-induced phosphorylation of AMPK $\alpha$ and ACC, particularly at $0.5 \mathrm{mM}$. Consistently, downregulation of AMPK $\alpha 1$ conferred partial resistance to $\mathrm{H}_{2} \mathrm{O}_{2}$ inhibition of mTOR signaling pathways (Figure 9a), as well as $\mathrm{H}_{2} \mathrm{O}_{2}$-induced cell death in SH-SY5Y cells (Figure 9b). 

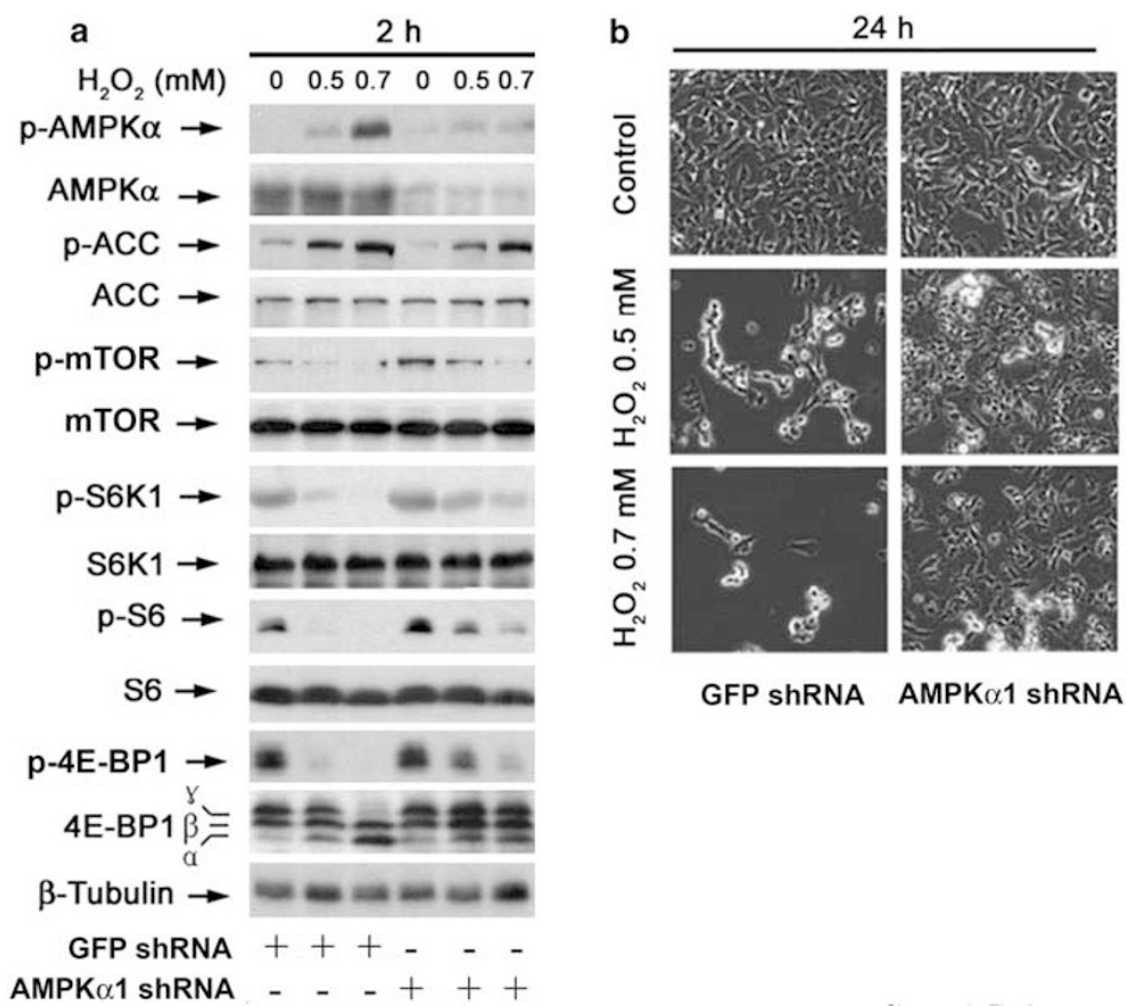

Figure 9 Downregulation of AMPK $\alpha 1$ partially prevents hydrogen peroxide inhibition of mTOR signaling and induction of neuronal cell death. (a) SH-SY5Y cells, infected with lentiviral shRNAs to human AMPK $\alpha 1$ and GFP (as control), were exposed to $\mathrm{H}_{2} \mathrm{O}_{2}(0.5,0.7$, and $1 \mathrm{mM}$ ) for $2 \mathrm{~h}$, followed by western blot analysis with indicated antibodies. The blots were probed for $\beta$-tubulin as a loading control. Similar results were observed in at least three independent experiments. (b) Morphology of lentiviral shRNA-infected SH-SY5Y cells, treated with/without $\mathrm{H}_{2} \mathrm{O}_{2}(0.5$ and $0.7 \mathrm{mM})$ for $24 \mathrm{~h}$, were assessed using an Olympus inverted phase-contrast microscope $(200 \times)$ equipped with Quick Imaging system.

\section{DISCUSSION}

Increasing evidence has implicated oxidative stress as one of critical factors leading to neuronal cell death in many neurodegenerative disorders, such as Alzheimer's disease, Parkinson's disease, Huntington's disease, and amyotrophic lateral sclerosis. ${ }^{2,31-39}$ However, how oxidative stress causes neuronal cell death is not well understood. mTOR has been widely recognized as a central controller for cell proliferation, growth, and survival. ${ }^{10,23}$ Recently, we have shown that $\mathrm{H}_{2} \mathrm{O}_{2}$ induces apoptosis in $\mathrm{PC} 12$ cells and primary murine neurons. ${ }^{9}$ Here, we show that $\mathrm{H}_{2} \mathrm{O}_{2}$ induction of neuronal cell death is in part associated with inhibition of mTOR signaling pathway. This is strongly supported by the findings (Figures 1-4) that (1) $\mathrm{H}_{2} \mathrm{O}_{2}$ treatment dramatically inhibited phosphorylation of mTOR, S6K1, and 4EBP1 in a concentration- and time-dependent manner; (2) the above event was blocked by NAC in PC12 cells and primary neurons; and (3) expression of wt-mTOR or constitutively active $\mathrm{S} 6 \mathrm{~K} 1$, or downregulation of $4 \mathrm{E}-\mathrm{BP} 1$ conferred partial resistance to $\mathrm{H}_{2} \mathrm{O}_{2}$ induction of neuronal cell death. In addition, we also noticed that inhibition of mTOR with rapamycin $(100 \mathrm{ng} / \mathrm{ml})$ alone did not significantly induce apoptosis of PC12 cells, though rapamycin slightly enhanced $\mathrm{H}_{2} \mathrm{O}_{2}$-induced cell death (data not shown). The results suggest that $\mathrm{H}_{2} \mathrm{O}_{2}$-induced neuronal cell death may involve more signaling pathways. At least JNK, Erk1/2, and p38 MAPK pathways have been described. ${ }^{9}$ Our results are in contrast to the findings in hepatoma (H4IIE) and epidermal (JB6) cells, ${ }^{40-44}$ but in agreement with the data from PC12 cells. ${ }^{45}$ Treatment of H4IIE or JB6 cells with $\mathrm{H}_{2} \mathrm{O}_{2}$ or its inducers, such as arsenite and ultraviolet irradiation, increased phosphorylation of $\mathrm{S6K} 1$, which was blocked by NAC or catalase (a specific $\mathrm{H}_{2} \mathrm{O}_{2}$ scavenger). ${ }^{40-44}$ Ultraviolet irradiation-induced $\mathrm{H}_{2} \mathrm{O}_{2}$ contributes to tumorigenesis. ${ }^{41}$ However, treatment of PC12 cells with $\mathrm{H}_{2} \mathrm{O}_{2}$ inhibited phosphorylation of $4 \mathrm{E}-\mathrm{BP} 1$ and initiation factor $4 \mathrm{E}$ (eIF4E), which was completely abolished by NAC. ${ }^{45}$ The findings in this study and others ${ }^{40-45}$ imply that the effect of $\mathrm{H}_{2} \mathrm{O}_{2}$ on cell fate or mTOR signaling, to some degree, may be dependent on cell type.

In the studies, we observed that $\mathrm{H}_{2} \mathrm{O}_{2}$ inhibited phosphorylation of 4E-BP1 (Thr70), but increased expression of hypophosphorylated forms ( $\alpha$ and $\beta$ bands) of 4E-BP1 in $\mathrm{PC} 12$ and primary murine neurons. It has been reported that decreased phosphorylation of $4 \mathrm{E}-\mathrm{BP} 1$ may increase the stability of $4 \mathrm{E}-\mathrm{BP} 1 .{ }^{46}$ With a great possibility, $\mathrm{H}_{2} \mathrm{O}_{2}$ inhibition of phosphorylation of 4E-BP1 may increase stability of $4 \mathrm{E}-\mathrm{BP} 1$, leading to increased expression of $\alpha$ and $\beta$ bands of $4 \mathrm{E}-\mathrm{BP} 1$. 
mTOR signaling is positively regulated by IGFR/Akt, and negatively regulated by AMPK and PTEN. ${ }^{10,23}$ Besides, activated PDK1 may positively regulate mTOR-mediated S6K1. ${ }^{10}$ To identify the mechanism by which $\mathrm{H}_{2} \mathrm{O}_{2}$ inhibits mTOR signaling in neuronal cells, first of all, we focused on the upstream kinases, IGFR, Akt, and PDK1. Our data show that $\mathrm{H}_{2} \mathrm{O}_{2}$ did not impact protein expression and tyrosine phosphorylation of IGFR $\beta$ (Figure 5), but inhibited phosphorylation of Akt and PDK1 in PC12 cells and primary neurons in a concentration-dependent manner (Figure 6). $\mathrm{H}_{2} \mathrm{O}_{2}$ inhibited PDK1 phosphorylation in a time-dependent manner, but activated Akt transiently within 10-30 min and then inhibited Akt in 1-2 h. The mechanism remains to be defined. Pretreatment with NAC, a ROS scavenger, dramatically prevented $\mathrm{H}_{2} \mathrm{O}_{2}$-reduced phosphorylation of Akt and PDK1 in the cells (Figure 6), revealing that $\mathrm{H}_{2} \mathrm{O}_{2}$ induction of ROS inhibits mTOR signaling is concurrently related to inhibition of Akt and PDK1, but not IGFR, in neuronal cells. PI3K is an upstream kinase of Akt and PDK1. ${ }^{23}$ Whether this is due to inhibition of PI3K remains to be determined.

In this study, we also observed that $\mathrm{H}_{2} \mathrm{O}_{2}$ failed to alter protein expression and phosphorylation of PTEN, but dramatically increased the activity of AMPK (Figure 7). $\mathrm{H}_{2} \mathrm{O}_{2}$ treatment resulted in increase of phosphorylation of AMPK $\alpha$ and its substrate, ACC, in a dose- and time-dependent manner in PC12 cells and primary neurons. Pretreatment with NAC inhibited $\mathrm{H}_{2} \mathrm{O}_{2}$ activation of AMPK $\alpha$. Clearly, NAC inhibited phosphorylation of AMPK $\alpha$ and ACC induced by $\mathrm{H}_{2} \mathrm{O}_{2}$ at $0.5 \mathrm{mM}$ than at $1 \mathrm{mM}$ more potently. Probably, at $1 \mathrm{mM}, \mathrm{H}_{2} \mathrm{O}_{2}$ activates AMPK through ROSindependent mechanism. Of importance, expression of dominant negative AMPK $\alpha$ or downregulation of AMPK $\alpha 1$ partially prevented $\mathrm{H}_{2} \mathrm{O}_{2}$ inhibition of phosphorylation of mTOR, S6K1, and 4E-BP1, as well as induction of cell death (Figures 8 and 9). In particular, in response to a higher concentration (1 mM) of $\mathrm{H}_{2} \mathrm{O}_{2}$, the protective effect of dominant negative AMPK $\alpha$ or AMPK $\alpha 1$ shRNA against $\mathrm{H}_{2} \mathrm{O}_{2}$-induced phosphorylation of ACC and apoptosis was marginal. We also noticed that overexpression of wild-type AMPK alone, like treatment with rapamycin alone, inhibited phosphorylation of mTOR and its downstream effector molecules, including S6K1 and 4E-BP1, but failed to induce significant apoptosis in PC12 cells (data not shown). However, overexpression of wt-AMPK did sensitize PC12 cells to $\mathrm{H}_{2} \mathrm{O}_{2}$-induced cell death (data not shown). The results are in agreement with the findings that AMPK/mTOR-independent pathways, such as JNK, Erk1/2, and p38 MAPK pathways, ${ }^{9}$ also contribute to $\mathrm{H}_{2} \mathrm{O}_{2}$-induced cell death. The above data indicate that $\mathrm{H}_{2} \mathrm{O}_{2}$ induction of ROS causes apoptosis of the neuronal cells at least in part through activation of AMPK $\alpha$ signaling, leading to inhibition of mTOR-mediated phosphorylation of S6K1 and 4E-BP1.

In summary, we have identified that oxidative stress by $\mathrm{H}_{2} \mathrm{O}_{2}$ inhibits mTOR-mediated phosphorylation of S6K1 and $4 \mathrm{E}-\mathrm{BP} 1$, leading to apoptosis of neuronal cells. $\mathrm{H}_{2} \mathrm{O}_{2}$ induction of ROS inhibits Akt and PDK1, but not IGFR; activates AMPK, but not PTEN. Expression of dominant negative AMPK $\alpha$ or downregulation of AMPK $\alpha 1$ conferred partial resistance to $\mathrm{H}_{2} \mathrm{O}_{2}$ inhibition of mTOR signaling and cell viability, indicating that $\mathrm{H}_{2} \mathrm{O}_{2}$ induction of ROS inhibits mTOR pathway at least in part by activating AMPK $\alpha$. Our findings suggest that AMPK inhibitors may be exploited for prevention of oxidative stress (eg $\mathrm{H}_{2} \mathrm{O}_{2}$ )-induced neurodegenerative diseases.

\section{ACKNOWLEDGEMENTS}

This work was supported in part by NIH CA115414 (S.H.), American Cancer Society Award \#RSG-08-135-01-CNE (S.H.), Louisiana Board of Regents Award \#NSF(2009)-PFUND-144 (S.H.), Feist-Weiller Cancer Research Award (S.H.), and a Start-up Fund (S.H.) jointly from Louisiana State University Health Sciences Center in Shreveport, LA.

\section{DISCLOSURE/CONFLICT OF INTEREST}

The authors declare no conflict of interest.

1. Baxter LC, Sparks DL, Johnson SC, et al. Relationship of cognitive measures and gray and white matter in Alzheimer's disease. J Alzheimers Dis 2006;9:253-260.

2. Ruffels J, Griffin M, Dickenson JM. Activation of ERK $1 / 2$, JNK and PKB by hydrogen peroxide in human SH-SY5Y neuroblastoma cells: role of ERK1/2 in H2O2-induced cell death. Eur J Pharmacol 2004;483: 163-173.

3. Stadtman E. Protein oxidation and aging. Science 1992;257: 1220-1224.

4. Stohs SJ, Bagchi D. Oxidative mechanisms in the toxicity of metal ions. Free Radic Biol Med 1995;18:321-336.

5. Figueiredo-Pereira ME, Yakushin S, Cohen G. Disruption of the intracellular sulfhydryl homeostasis by cadmium-induced oxidative stress leads to protein thiolation and ubiquitination in neuronal cells. J Biol Chem 1998;273:12703-12709.

6. Green KN, Peers C. Divergent pathways account for two distinct effects of amyloid beta peptides on exocytosis and $\mathrm{Ca}^{2+}$ currents: involvement of ROS and NF- $\kappa$ B. J Neurochem 2002;81:1043-1051.

7. Li Z, Arnaud L, Rockwell $P$, et al. A single amino acid substitution in a proteasome subunit triggers aggregation of ubiquitinated proteins in stressed neuronal cells. J Neurochem 2004;90:19-28.

8. Kim S, Moon C, Eun S, et al. Identification of ASK1, MKK4, JNK, c-Jun, and caspase- 3 as a signaling cascade involved in cadmium-induced neuronal cell apoptosis. Biochem Biophys Res Commun 2005;328: 326-334.

9. Chen L, Liu L, Yin J, et al. Hydrogen peroxide-induced neuronal apoptosis is associated with inhibition of protein phosphatase $2 \mathrm{~A}$ and 5 , leading to activation of MAPK pathway. Int J Biochem Cell Biol 2009;41:1284-1295.

10. Ma XM, Blenis J. Molecular mechanisms of mTOR-mediated translational control. Nat Rev Mol Cell Biol 2009;10:307-318.

11. Sarbassov DD, Guertin DA, Ali SM, et al. Phosphorylation and regulation of Akt/PKB by the rictor-mTOR complex. Science 2005;307:1098-1101.

12. Gao $X$, Zhang $Y$, Arrazola $P$, et al. Tsc tumour suppressor proteins antagonize amino-acid-TOR signalling. Nat Cell Biol 2002;4:699-704.

13. Inoki $\mathrm{K}, \mathrm{Li} \mathrm{Y}, \mathrm{Zhu} \mathrm{T}$, et al. TSC2 is phosphorylated and inhibited by Akt and suppresses mTOR signalling. Nat Cell Biol 2002;4:648-657.

14. Tee AR, Fingar DC, Manning BD, et al. Tuberous sclerosis complex-1 and -2 gene products function together to inhibit mammalian target of rapamycin (mTOR)-mediated downstream signaling. Proc Natl Acad Sci USA 2002;99:13571-13576.

15. Stocker H, Radimerski T, Schindelholz B, et al. Rheb is an essential regulator of S6K in controlling cell growth in Drosophila. Nat Cell Biol 2003;5:559-565. 
16. Zhang $Y$, Gao X, Saucedo $L$, et al. Rheb is a direct target of the tuberous sclerosis tumour suppressor proteins. Nat Cell Biol 2003:5:578-581.

17. Garami A, Zwartkruis FJ, Nobukuni T, et al. Insulin activation of Rheb, a mediator of mTOR/S6K/4E-BP signaling, is inhibited by TSC1 and 2. Mol Cell 2003;11:1457-1466.

18. Inoki $\mathrm{K}, \mathrm{Li} \mathrm{Y}, \mathrm{Xu} \mathrm{T}$, et al. Rheb GTPase is a direct target of TSC2 GAP activity and regulates mTOR signaling. Genes Dev 2003;17:1829-1834.

19. Tee AR, Manning BD, Roux PP, et al. Tuberous sclerosis complex gene products, Tuberin and Hamartin, control mTOR signaling by acting as a GTPase-activating protein complex toward Rheb. Curr Biol 2003;13:1259-1268.

20. Manning BD, Cantley LC. Rheb fills a GAP between TSC and TOR. Trends Biochem Sci 2003;28:573-576.

21. Bai $X, M a D$, Liu A, et al. Rheb activates mTOR by antagonizing its endogenous inhibitor, FKBP38. Science 2007;318:977-980.

22. Wang $\mathrm{X}$, Fonseca $\mathrm{BD}$, Tang $\mathrm{H}$, et al. Re-evaluating the roles of proposed modulators of mammalian target of rapamycin complex 1 (mTORC1) signaling. J Biol Chem 2008;283:30482-30492.

23. Wullschleger $\mathrm{S}$, Loewith $\mathrm{R}$, Hall MN. TOR signaling in growth and metabolism. Cell 2006;124:471-484.

24. Winder WW. Energy-sensing and signaling by AMP-activated protein kinase in skeletal muscle. J Appl Physiol 2001;91:1017-1028.

25. Hardie DG. AMP-activated/SNF1 protein kinases: conserved guardians of cellular energy. Nat Rev Mol Cell Biol 2007;8:774-785.

26. Vilella-Bach $M$, Nuzzi $P$, Fang $Y$, et al. The FKBP12-rapamycin-binding domain is required for FKBP12-rapamycin-associated protein kinase activity and G1 progression. J Biol Chem 1999;274:4266-4272.

27. He TC, Zhou S, da Costa LT, et al. A simplified system for generating recombinant adenoviruses. Proc Natl Acad Sci USA 1998;95:2509-2514.

28. Liu L, Chen L, Chung J, et al. Rapamycin inhibits F-actin reorganization and phosphorylation of focal adhesion proteins. Oncogene 2008:27:4998-5010.

29. Lu M, Tang Q, Olefsky JM, et al. Adiponectin activates adenosine monophosphate-activated protein kinase and decreases luteinizing hormone secretion in LbetaT2 gonadotropes. Mol Endocrinol 2008;22:760-777.

30. Brunn GJ, Hudson CC, uliæ A, et al. Phosphorylation of the translational repressor PHAS-I by the mammalian target of rapamycin. Science 1997:277:99-101.

31. Behl C, Davis JB, Lesley $R$, et al. Hydrogen peroxide mediates amyloid beta protein toxicity. Cell 1994;77:817-827.
32. Owen AD, Schapira AH, Jenner $P$, et al. Oxidative stress and Parkinson's disease. Ann NY Acad Sci 1996;786:217-223.

33. Behl C. Alzheimer's disease and oxidative stress: implications for novel therapeutic approaches. Prog Neurobiol 1999;57:301-323.

34. Alexi T, Borlongan CV, Faull RL, et al. Neuroprotective strategies for basal ganglia degeneration: Parkinson's and Huntington's diseases. Prog Neurobiol 2000;60:409-470.

35. Christen Y. Oxidative stress and Alzheimer disease. Am J Clin Nutr 2000;71:621S-629S.

36. Jellinger KA. Cell death mechanisms in Parkinson's disease. J Neural Transm 2000;107:1-29.

37. Rottkamp CA, Nunomura A, Raina AK, et al. Oxidative stress, antioxidants, and Alzheimer disease. Alzheimer Dis Assoc Disord 2000;14(Suppl 1):S62-S66.

38. Zhang Y, Dawson VL, Dawson TM. Oxidative stress and genetics in the pathogenesis of Parkinson's disease. Neurobiol Dis 2000;7:240-250.

39. Wu DC, Re DB, Nagai $M$, et al. The inflammatory NADPH oxidase enzyme modulates motor neuron degeneration in amyotrophic lateral sclerosis mice. Proc Natl Acad Sci USA 2006;103:12132-12137.

40. Bae G-U, Seo D-W, Kwon H-K, et al. Hydrogen peroxide activates p70S6k signaling pathway. J Biol Chem 1999;274:32596-32602.

41. Huang C, Li J, Ke Q, et al. Ultraviolet-induced phosphorylation of p70(S6K) at Thr(389) and $\operatorname{Thr}(421) / S e r(424)$ involves hydrogen peroxide and mammalian target of rapamycin but not Akt and atypical protein kinase C. Cancer Res 2002;62:5689-5697.

42. Jung DK, Bae GU, Kim YK, et al. Hydrogen peroxide mediates arsenite activation of p70(s6k) and extracellular signal-regulated kinase. Exp Cell Res 2003;290:144-154.

43. Radisavljevic ZM, Gonzalez-Flecha B. TOR kinase and Ran are downstream from PI3K/Akt in $\mathrm{H} 2 \mathrm{O} 2$-induced mitosis. J Cell Biochem 2004;91:1293-1300.

44. Kimball SR, Abbas A, Jefferson LS. Melatonin represses oxidative stressinduced activation of the MAP kinase and mTOR signaling pathways in H4IIE hepatoma cells through inhibition of Ras. J Pineal Res 2008;44:379-386.

45. O'Loghlen A, Perez-Morgado MI, Salinas M, et al. N-acetyl-cysteine abolishes hydrogen peroxide-induced modification of eukaryotic initiation factor 4F activity via distinct signalling pathways. Cell Signal 2006;18:21-31.

46. Elia A, Constantinou C, Clemens MJ. Effects of protein phosphorylation on ubiquitination and stability of the translational inhibitor protein $4 \mathrm{E}-$ BP1. Oncogene 2008;27:811-822. 